\title{
Photoactive building blocks for coordination complexes: gilding 2,2':6',2"'-terpyridine
}

\author{
Edwin C. Constable,* Catherine E. Housecroft,* Marzena K. Kocik and Jennifer A. \\ Zampese \\ Department of Chemistry, University of Basel, Spitalstrasse 51,4056-Basel, Switzerland \\ Fax: +4161267 1018; E-mail: catherine.housecroft@unibas.ch
}

\begin{abstract}
The alkyne unit of 4'-ethynyl-2,2':6',2"-terpyridine has been functionalized with $\mathrm{Ph}_{3} \mathrm{PAu}$, (2-tolyl) ${ }_{3} \mathrm{PAu}$ or $\mathrm{Au}(\mathrm{dppe}) \mathrm{Au}$ units to produce compounds 1-3, respectively. These derivatives have been characterized by electrospray mass spectrometry, solution ${ }^{1} \mathrm{H}$ and ${ }^{13} \mathrm{C}$ NMR, UV-VIS and emission spectroscopies, and single crystal X-ray diffraction. In the solid state, molecules of $\mathbf{1}$ or $\mathbf{2}$ pack with separated domains of tpy and $\mathrm{R}_{3} \mathrm{PAu}$ units; the tpy units in $\mathbf{2}$ (but not $\mathbf{1}$ ) exhibit face-to-face $\pi$-stacking. Compound $\mathbf{3}$ crystallizes as $2(3) \cdot \mathrm{CHCl}_{3}$, and the folded conformation of the dppe backbone results in a short (2.9470(8) A) aurophilic interaction. Folded molecule 3 captures $\mathrm{CHCl}_{3}$, preventing intramolecular face-to-face $\pi$-interactions between the tpy units. In $\mathrm{CH}_{2} \mathrm{Cl}_{2}$ solution, 1-3 are emissive when excited between 230 and $300 \mathrm{~nm}$, but over minutes when $\lambda_{\mathrm{ex}}=230$ $\mathrm{nm}$, the emission bands decay as the compounds photodegrade.
\end{abstract}

Keywords: Gold(I); 2,2':6',2"-terpyridine; phosphane; alkyne; photophysics 


\section{Introduction}

Gold(I) alkynyl complexes [1,2] containing gold atoms in linear coordination environments are popular building blocks for polymeric and macrocyclic organometallic assemblies [3-12]. The luminescent properties of gold(I) species $[13,14]$ and the ease of synthesis of gold(I) alkynyls make them attractive candidates for derivatization of other metal-binding domains such as pyridine [15-19], 2,2'bipyridine (bpy) [16,20,21] and 2,2':6',2"-terpyridine (tpy) [21,22]. The combination of a luminescent gold(I) unit and a chelating ligand provides an approach to the design of metal ion sensors.

In gold(I) derivatives, aurophilic interactions (i.e. short Au...Au contact of around 3.00-3.20 A) [23] are considered important in influencing their emissive behaviour [24,25]. Recently, we reported the solid-state structures of four bis(gold(I) phosphane)-decorated 4,4'-diethynyl-2,2'-bipyridines (Scheme 1) [20]. Changing the phosphane from $\mathrm{PEt}_{3}$ to $\mathrm{P}^{\mathrm{i}} \mathrm{Pr}_{3}$ alters the packing, producing different polymeric chain motifs. In both, Au...Au contacts of less than $3.4 \AA$ are observed. For the more sterically demanding $\mathrm{PPh}_{3}$ and $\mathrm{P}(4 \text {-tolyl })_{3}$ substituents, no short $\mathrm{Au}$....Au contacts are present in the solid state. In $\mathrm{CH}_{2} \mathrm{Cl}_{2}$ solution, each compound (Scheme 1) is a dual emitter at room temperature. However, with $\lambda_{\mathrm{ex}} \approx 238 \mathrm{~nm}$, the emission spectra decay quite rapidly at the expense of a new set of emission maxima, and we have proposed that this arises from cleavage of the $\mathrm{Au}-\mathrm{C}_{\text {alkyne }}$ bond. We now turn our attention to tpy-based compounds in which the alkynyl substituent is directly attached to the 4'position of the tpy domain. This is in contrast to previously reported systems in which the tpy and $\mathrm{C} \equiv \mathrm{C}$ units are separated by an arene spacer $[21,22]$. 


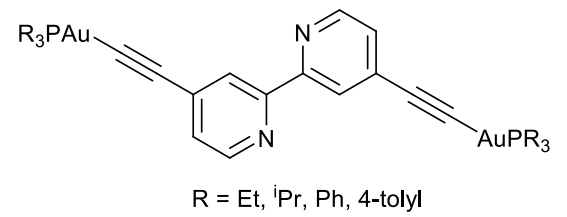

Scheme 1 Previously reported bis(gold(I) phosphane)-4,4'-diethynyl-2,2'-bipyridine compounds [20].

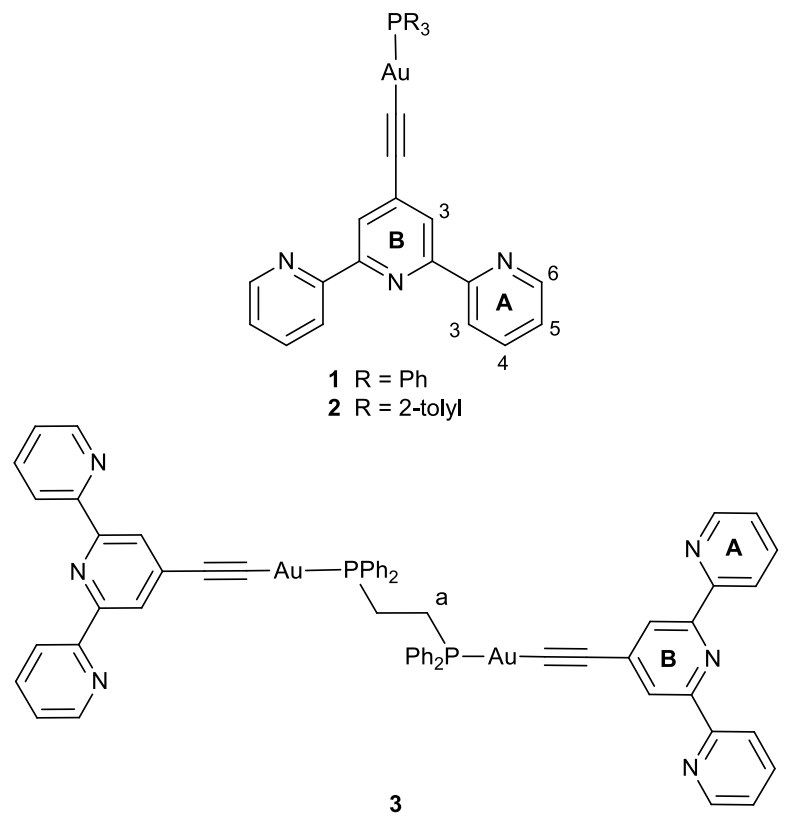

Scheme 2 Structures of compounds 1-3 with numbering schemes for NMR spectroscopic assignments. Phenyl and 2-tolyl rings are labelled $\mathbf{C}$.

\section{Experimental}

\subsection{General procedures}

${ }^{1} \mathrm{H}$ and ${ }^{13} \mathrm{C}$ NMR spectra were recorded on a Bruker DRX-500 NMR spectrometer with chemical shifts referenced to residual solvent peaks $\left(\mathrm{CHCl}_{3}=\delta 7.24 \mathrm{ppm}\right.$, TMS $=\delta 0 \mathrm{ppm}) .{ }^{31} \mathrm{P}$ NMR spectra were recorded using a Bruker DRX-400 NMR spectrometer and were referenced with respect to $85 \% \mathrm{H}_{3} \mathrm{PO}_{4}=\delta 0 \mathrm{ppm}$. Absorption spectra were recorded using a Varian-Cary 5000 spectrophotometer and emission spectra using a Shimadzu RF-5301 PC spectrofluorometer; excitation/emission slit widths were set at $3 / 3,5 / 3,3 / 3$, and $5 / 5$ for 4 '-ethynyl-2,2':6',2"-terpyridine, $\mathbf{1}, 2$ and 
3, respectively. Electrospray ionization (ESI) mass spectra were measured with a Bruker esquire $3000^{\text {plus }}$ mass spectrometer.

4'-Ethynyl-2,2':6',2"-terpyridine was prepared according to the literature procedure starting from 4'-[(trifluoromethylsulfonyl)oxy]-2,2':6',2"-terpyridine [26]. $\mathrm{R}_{3} \mathrm{PAuCl}$ with $\mathrm{R}=\mathrm{Ph}$ or 2-tolyl was prepared by a reported route [27] with a reaction temperature of $-5^{\circ} \mathrm{C}$. Abbreviation: tht $=$ tetrahydrothiophene.

\section{$2.2\left\{A u\left(4^{\prime}-C \equiv C t p y\right)\right\} n$}

The synthesis of $\left\{\mathrm{Au}\left(4^{\prime}-\mathrm{C} \equiv \mathrm{Ctpy}\right)\right\}_{n}$ was based on that described for $\{\mathrm{Au}(4-\mathrm{C} \equiv \mathrm{Cpy})\}_{n}$ [17]. 4'-Ethynyl-2,2':6',2"-terpyridine (50 mg, $190 \mu \mathrm{mol}),[($ tht $) \mathrm{AuCl}](63.5 \mathrm{mg}, 190$ $\mu \mathrm{mol})$ and NaOAc $(77.9 \mathrm{mg}, 950 \mu \mathrm{mol})$ were added to a mixture of THF $\left(5 \mathrm{~cm}^{3}\right)$ and $\mathrm{MeOH}\left(5 \mathrm{~cm}^{3}\right)$ under argon and with light excluded. The reaction mixture was stirred for 6-12 h after which time a pale yellow precipitate was obtained. This was collected by filtration and washed with $\mathrm{MeOH} .\left\{\mathrm{Au}\left(4^{\prime}-\mathrm{C} \equiv \mathrm{Ctpy}\right)\right\}_{n}$ was isolated as yellow solid (72 mg, $159 \mu \mathrm{mol}$, ca. $82 \%$ ) and was used without further purification.

\subsection{Compound 1}

$\mathrm{Ph}_{3} \mathrm{PAuCl}(38 \mathrm{mg}, 78 \mu \mathrm{mol}), 4^{\prime}-$ ethynyl-2,2':6',2"-terpyridine (20 mg, $\left.78 \mu \mathrm{mol}\right), \mathrm{CuI}$ $(0.7 \mathrm{mg}, 4 \mu \mathrm{mol})$ were dissolved in $\mathrm{CH}_{2} \mathrm{Cl}_{2}\left(8 \mathrm{~cm}^{3}\right)$ and $\mathrm{MeOH}\left(2 \mathrm{~cm}^{3}\right)$. NaOAc (13 $\mathrm{mg}, 156 \mu \mathrm{mol})$ was then added, and the reaction mixture stirred at room temperature in the dark for $12-16 \mathrm{~h}$. It was then filtered and the solvent removed from the filtrate in vacuo. The crude material was purified by preparative plate chromatography in the dark $\left(\mathrm{Al}_{2} \mathrm{O}_{3}, \mathrm{CH}_{2} \mathrm{Cl}_{2}\right)$. 1 was isolated as a white solid $(39.3 \mathrm{mg}, 55.3 \mu \mathrm{mol}, 70.7 \%)$. 
${ }^{1} \mathrm{H}$ NMR $\left(500 \mathrm{MHz}, \mathrm{CDCl}_{3}\right) \delta / \operatorname{ppm} 8.66\left(\mathrm{~d}, J=4.0 \mathrm{~Hz}, 2 \mathrm{H}, \mathrm{H}^{\mathrm{A} 6}\right), 8.54(\mathrm{~d}, J=8.1$ $\left.\mathrm{Hz}, 2 \mathrm{H}, \mathrm{H}^{\mathrm{A} 3}\right), 8.52\left(\mathrm{~s}, 2 \mathrm{H}, \mathrm{H}^{\mathrm{B} 3}\right), 7.80\left(\mathrm{td}, J=7.8,1.7 \mathrm{~Hz}, 2 \mathrm{H}, \mathrm{H}^{\mathrm{A} 4}\right), 7.54(\mathrm{~m}, 6 \mathrm{H}$, $\left.\mathrm{H}^{\mathrm{C} 2 / \mathrm{C} 3}\right), 7.49\left(\mathrm{~m}, 3 \mathrm{H}, \mathrm{H}^{\mathrm{C} 4}\right), 7.45\left(\mathrm{~m}, 6 \mathrm{H}, \mathrm{H}^{\mathrm{C} 2 / \mathrm{C} 3}\right), 7.29\left(\mathrm{~m}, 2 \mathrm{H}, \mathrm{H}^{\mathrm{A} 5}\right) .{ }^{13} \mathrm{C}$ NMR $(126$ $\left.\mathrm{MHz}, \mathrm{CDCl}_{3}\right) \delta /$ ppm $156.5\left(\mathrm{C}^{\mathrm{A} 2}\right), 155.4\left(\mathrm{C}^{\mathrm{B} 2}\right), 149.4\left(\mathrm{C}^{\mathrm{A} 6}\right), 136.8\left(\mathrm{C}^{\mathrm{A} 4}\right), 135.3\left(\mathrm{C}^{\mathrm{B} 4}\right)$, $134.5\left(\mathrm{~d}, J_{\mathrm{PC}}=14 \mathrm{~Hz}, \mathrm{C}^{\mathrm{C} 2 / \mathrm{C} 3}\right), 131.8\left(\mathrm{~d}, J_{\mathrm{PC}}=2 \mathrm{~Hz}, \mathrm{C}^{\mathrm{C} 4}\right), 129.6\left(\mathrm{~d}, J_{\mathrm{PC}}=56 \mathrm{~Hz}, \mathrm{C}^{\mathrm{C} 1}\right)$, $129.4\left(\mathrm{~d}, J_{\mathrm{PC}}=11 \mathrm{~Hz}, \mathrm{C}^{\mathrm{C} 2 / \mathrm{C} 3}\right), 124.3\left(\mathrm{C}^{\mathrm{B} 3}\right), 123.7\left(\mathrm{C}^{\mathrm{A} 5}\right), 121.3\left(\mathrm{C}^{\mathrm{A} 3}\right), 102.3$ (poorly resolved, $C \equiv \mathrm{CAu})$, signal for $\mathrm{C} \equiv C \mathrm{Au}$ not observed. ${ }^{31} \mathrm{P} \mathrm{NMR}\left(162 \mathrm{MHz}, \mathrm{CDCl}_{3}\right) \delta /$ ppm 42.4. UV/VIS $\lambda_{\max } / \mathrm{nm}\left(\mathrm{CH}_{2} \mathrm{Cl}_{2}\right) 229\left(\varepsilon / \mathrm{dm}^{3} \mathrm{~mol}^{-1} \mathrm{~cm}^{-1} 53000\right), 244$ (50000), 277 (54000), 289 (62000), 319 (9000), 331 (6000). Emission $\left(\mathrm{CH}_{2} \mathrm{Cl}_{2}, \lambda_{\mathrm{exc}}=244 \mathrm{~nm}\right)$ $\lambda_{\mathrm{em}} / \mathrm{nm} 339$, 355. ESI MS $\left(\mathrm{CH}_{2} \mathrm{Cl}_{2} / \mathrm{MeOH}\right) m / z 1174.4\left[\mathrm{M}+\mathrm{AuPPh}_{3}\right]^{+}$(calc. 1174.2), $716.3[\mathrm{M}+\mathrm{H}]^{+}$(base peak, calc. 716.2). Found $\mathrm{C} 58.55, \mathrm{H} \mathrm{3.72,} \mathrm{N}$ 5.92; $\mathrm{C}_{35} \mathrm{H}_{25} \mathrm{AuN}_{3} \mathrm{P}$ requires C 58.75, H 3.52, N 5.87\%.

\subsection{Compound 2}

The method was as for $\mathbf{1}$, starting with (2-tolyl) ${ }_{3} \mathrm{PAuCl}(42 \mathrm{mg}, 78 \mu \mathrm{mol}), 4^{\prime}$-ethynyl2,2':6',2"-terpyridine (20 mg, $78 \mu \mathrm{mol}), \mathrm{NaOAc}(13 \mathrm{mg}, 156 \mu \mathrm{mol})$ and $\mathrm{CuI}(0.7 \mathrm{mg}$, $4 \mu \mathrm{mol})$. Compound 2 was isolated as a white solid $(36.2 \mathrm{mg}, 47.8 \mu \mathrm{mol}, 61.6 \%) .{ }^{1} \mathrm{H}$ $\operatorname{NMR}\left(500 \mathrm{MHz}, \mathrm{CDCl}_{3}\right) \delta / \operatorname{ppm} 8.68\left(\mathrm{dd}, J=4.6,0.8 \mathrm{~Hz}, 2 \mathrm{H}, \mathrm{H}^{\mathrm{A} 6}\right), 8.53(\mathrm{~d}, J=7.9$ $\left.\mathrm{Hz}, 2 \mathrm{H}, \mathrm{H}^{\mathrm{A} 3}\right), 8.48\left(\mathrm{~s}, 2 \mathrm{H}, \mathrm{H}^{\mathrm{B} 3}\right), 7.79\left(\mathrm{td}, J=7.7,1.8 \mathrm{~Hz}, 2 \mathrm{H}, \mathrm{H}^{\mathrm{A} 4}\right), 7.44(\mathrm{t}, J=7.5 \mathrm{~Hz}$ $\left.3 \mathrm{H}, \mathrm{H}^{\mathrm{C} 4}\right), 7.36\left(\mathrm{~m}, 3 \mathrm{H}, \mathrm{H}^{\mathrm{C} 3}\right), 7.26\left(\mathrm{ddd}, J=7.4,4.8,1.0 \mathrm{~Hz}, 2 \mathrm{H}, \mathrm{H}^{\mathrm{A} 5}\right), 7.17(\mathrm{t}, J=7.6$ $\left.\mathrm{Hz}, 3 \mathrm{H}, \mathrm{H}^{\mathrm{C} 5}\right), 6.93\left(\mathrm{dd}, J_{\mathrm{PH}}=12.2 \mathrm{~Hz}, J_{\mathrm{HH}}=7.7 \mathrm{~Hz}, 3 \mathrm{H}, \mathrm{H}^{\mathrm{C} 6}\right), 2.73\left(\mathrm{~s}, 9 \mathrm{H}, \mathrm{H}^{\mathrm{Me}}\right) .{ }^{13} \mathrm{C}$ NMR $\left(126 \mathrm{MHz}, \mathrm{CDCl}_{3}\right) \delta / \mathrm{ppm} 156.3\left(\mathrm{C}^{\mathrm{A} 2}\right), 155.1\left(\mathrm{C}^{\mathrm{B} 2}\right), 151.1\left(\mathrm{C}^{\mathrm{A} 6}\right), 149.1\left(\mathrm{~d}, J_{\mathrm{PC}}\right.$ $\left.=13 \mathrm{~Hz}, \mathrm{C}^{\mathrm{C} 2}\right), 136.6\left(\mathrm{C}^{\mathrm{A} 4}\right), 135.4\left(\mathrm{C}^{\mathrm{B} 4}\right), 133.6\left(\mathrm{~d}, J_{\mathrm{PC}}=8 \mathrm{~Hz}, \mathrm{C}^{\mathrm{C} 6}\right), 132.2\left(\mathrm{~d}, J_{\mathrm{PC}}=9\right.$ 
$\left.\mathrm{Hz}, \mathrm{C}^{\mathrm{C} 3}\right), 131.6\left(\mathrm{~d}, J_{\mathrm{PC}}=2 \mathrm{~Hz}, \mathrm{C}^{\mathrm{C} 4}\right), 126.6\left(\mathrm{~d}, J_{\mathrm{PC}}=9 \mathrm{~Hz}, \mathrm{C}^{\mathrm{C} 5}\right), 126.2\left(\mathrm{~d}, J_{\mathrm{PC}}=55 \mathrm{~Hz}\right.$ $\left.\mathrm{C}^{\mathrm{C} 1}\right), 124.0\left(\mathrm{C}^{\mathrm{B} 3}\right), 123.5\left(\mathrm{C}^{\mathrm{A} 5}\right), 121.1\left(\mathrm{C}^{\mathrm{A} 3}\right), 102.4\left(\mathrm{~d}, J_{\mathrm{PC}}=26.6 \mathrm{~Hz}, C \equiv \mathrm{CAu}\right), 23.7(\mathrm{~d}$, $\left.J=11 \mathrm{~Hz}, \mathrm{C}^{\mathrm{Me}}\right)$, signal for $\mathrm{C} \equiv C \mathrm{Au}$ not observed. ${ }^{31} \mathrm{P}$ NMR $\left(162 \mathrm{MHz}, \mathrm{CDCl}_{3}\right) \delta /$ ppm 24.3. UV/VIS $\lambda_{\max } / \mathrm{nm}\left(\mathrm{CH}_{2} \mathrm{Cl}_{2}\right), 251\left(\varepsilon / \mathrm{dm}^{3} \mathrm{~mol}^{-1} \mathrm{~cm}^{-1} 53000\right), 280$ (59000), 288 (64000), 318 (9000), 332 (6000). Emission $\left(\mathrm{CH}_{2} \mathrm{Cl}_{2}, \lambda_{\mathrm{exc}}=252 \mathrm{~nm}\right) \lambda_{\mathrm{em}} / \mathrm{nm}$ 341, 354. ESI MS $\left(\mathrm{CH}_{2} \mathrm{Cl}_{2} / \mathrm{MeOH}\right) \mathrm{m} / z$ 1258.5 $\left[\mathrm{M}+\mathrm{AuP}(\text { tolyl })_{3}\right]^{+}$(calc. 1258.3), 805.2 $\left[\mathrm{Au}\left\{\mathrm{P}(\text { tolyl })_{3}\right\}_{2}\right]^{+}$(calc. 805.2), $758.4[\mathrm{M}+\mathrm{H}]^{+}$(base peak, calc. 758.2). Found C 59.14, H 4.11, N 5.38; $\mathrm{C}_{38} \mathrm{H}_{31} \mathrm{AuN}_{3} \mathrm{P} \cdot \mathrm{H}_{2} \mathrm{O}$ requires $\mathrm{C} 58.84, \mathrm{H} 4.29, \mathrm{~N} 5.42 \%$.

\section{$2.4 \quad$ Compound 3}

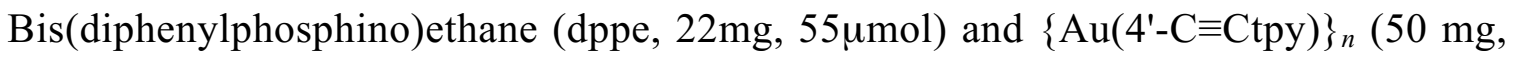
$110 \mu \mathrm{mol})$ were stirred in $\mathrm{CH}_{2} \mathrm{Cl}_{2}\left(10 \mathrm{~cm}^{3}\right)$ for $30-60 \mathrm{~min}$. After this time, the solvent was evaporated in vacuo and the crude product was purified in the dark by preparative plate chromatography $\left(\mathrm{Al}_{2} \mathrm{O}_{3}, \mathrm{CH}_{2} \mathrm{Cl}_{2}\right)$. Compound $\mathbf{3}$ was isolated as white solid (31.2 mg, $23.9 \mu \mathrm{mol}, 43.4 \%) .{ }^{1} \mathrm{H}$ NMR $\left(500 \mathrm{MHz}, \mathrm{CDCl}_{3}\right) \delta / \mathrm{ppm} 8.68(\mathrm{~d}, J=4.6 \mathrm{~Hz}, 4 \mathrm{H}$, $\left.\mathrm{H}^{\mathrm{A} 6}\right), 8.56\left(\mathrm{~d}, J=8.0 \mathrm{~Hz}, 4 \mathrm{H}, \mathrm{H}^{\mathrm{A} 3}\right), 8.55\left(\mathrm{~s}, 4 \mathrm{H}, \mathrm{H}^{\mathrm{B} 3}\right), 7.82(\mathrm{td}, J=7.8,1.5 \mathrm{~Hz}, 4 \mathrm{H}$, $\left.\mathrm{H}^{\mathrm{A} 4}\right), 7.72\left(\mathrm{~m}, 8 \mathrm{H}, \mathrm{H}^{\mathrm{C} 2}\right), 7.52$ (overlapping $\left.\mathrm{m}, 12 \mathrm{H}, \mathrm{H}^{\mathrm{C} 3 / \mathrm{C} 4}\right), 7.38\left(\mathrm{~m}, 4 \mathrm{H}, \mathrm{H}^{\mathrm{A} 5}\right), 2.69$ $\left(\mathrm{s}, 4 \mathrm{H}, \mathrm{H}^{\mathrm{a}}\right) \cdot{ }^{13} \mathrm{C}$ NMR $\left(126 \mathrm{MHz}, \mathrm{CDCl}_{3}\right) \delta / \mathrm{ppm} 156.2\left(\mathrm{C}^{\mathrm{A} 2}\right), 155.3\left(\mathrm{C}^{\mathrm{B} 2}\right), 149.2$ $\left(\mathrm{C}^{\mathrm{A} 6}\right), 136.7\left(\mathrm{C}^{\mathrm{A} 4}\right), 135.0\left(\mathrm{C}^{\mathrm{B} 5}\right), 133.5\left(\mathrm{C}^{\mathrm{C} 2}\right), 132.3\left(\mathrm{C}^{\mathrm{C} 4}\right), 129.7\left(\mathrm{t}, J_{\mathrm{PC}}=6 \mathrm{~Hz}, \mathrm{C}^{\mathrm{C} 3}\right)$, $124.0\left(\mathrm{C}^{\mathrm{B} 3}\right), 123.7\left(\mathrm{C}^{\mathrm{A} 5}\right), 121.2\left(\mathrm{C}^{\mathrm{A} 3}\right), 102.0$ (poorly resolved, $\left.C \equiv \mathrm{CAu}\right), 24.0\left(J_{\mathrm{PC}}=\right.$ $\left.17 \mathrm{~Hz}, \mathrm{C}^{\mathrm{a}}\right)$, signals for $\mathrm{C}^{\mathrm{C} 1}$ and $\mathrm{C} \equiv C \mathrm{Au}$ not observed. ${ }^{31} \mathrm{P}$ NMR $\left(162 \mathrm{MHz}, \mathrm{CDCl}_{3}\right) \delta /$ ppm 40.6. UV/VIS $\lambda_{\max } / \mathrm{nm}\left(\mathrm{CH}_{2} \mathrm{Cl}_{2}\right) 230\left(\varepsilon / \mathrm{dm}^{3} \mathrm{~mol}^{-1} \mathrm{~cm}^{-1} 122000\right), 239$ (116000), 254 (100000), 277 (136000), 289 (156000), 319 (26000), 332 (19000). Emission 
$\left(\mathrm{CH}_{2} \mathrm{Cl}_{2}, \lambda_{\mathrm{exc}}=241 \mathrm{~nm}\right) \lambda_{\mathrm{em}} / \mathrm{nm} 341,355$. ESI MS $\left(\mathrm{CH}_{2} \mathrm{Cl}_{2}\right) \mathrm{m} / z 1305.8[\mathrm{M}+\mathrm{H}]^{+}$ (calc. 1305.3), 1048.6 [Au(dppe)AuCCtpy $]^{+}$(calc. 1048.2), $993.7\left[(\mathrm{dppe}){ }_{2} \mathrm{Au}\right]^{+}(\mathrm{calc}$. 993.2). Found $\mathrm{C} 53.76, \mathrm{H} 3.41, \mathrm{~N} 6.00 ; \mathrm{C}_{60} \mathrm{H}_{44} \mathrm{Au}_{2} \mathrm{~N}_{6} \mathrm{P}_{2} \cdot 2 \mathrm{H}_{2} \mathrm{O}$ requires $\mathrm{C} 53.74, \mathrm{H}$ $3.61, \mathrm{~N} 6.27 \%$.

\subsection{Crystal structure determinations}

Data were collected on a Stoe IPDS diffractometer and the data reduction, solution and refinement used Stoe IPDS software [28] and SHELXL97 [29]. ORTEP figures were drawn using Ortep-3 for Windows [30], and the structures were analysed using Mercury v. 2.4 [31,32].

\subsection{Compound 1}

$\mathrm{C}_{35} \mathrm{H}_{25} \mathrm{AuN}_{3} \mathrm{P}, M=715.52$, colourless plate, monoclinic, space group $P 2_{1} / c, a=$ 19.658(4), $b=8.3726(17), c=17.853(4) \AA, \beta=105.39(3)^{\circ}, U=2833.0(10) \AA^{3}, Z=$ 4, $D_{c}=1.678 \mathrm{Mg} \mathrm{m}^{-3}, \mu\left(\mathrm{Mo}_{-} \mathrm{K}_{a}\right)=5.279 \mathrm{~mm}^{-1}, T=173 \mathrm{~K}$. Total 44788 reflections, 5835 unique, $R_{\text {int }}=0.0979$. Refinement of 5641 reflections (361 parameters) with $I$ $>2 \sigma(I)$ converged at final $R 1=0.0426(R 1$ all data $=0.0435), w R 2=0.1087(w R 2$ all data $=0.1098)$, gof $=1.144$

\subsection{Compound 2}

$\mathrm{C}_{38} \mathrm{H}_{31} \mathrm{AuN}_{3} \mathrm{P}, M=757.60$, colourless plate, triclinic, space group $P-1, a=9.2574(9)$, $b=17.6618(19), c=19.504(2) \AA, \alpha=107.172(8), \beta=96.023(8), \gamma=91.372(8)^{\circ}, U=$ 3024.9(5) $\AA^{3}, Z=4, D_{c}=1.664 \mathrm{Mg} \mathrm{m}^{-3}, \mu\left(\mathrm{Mo}_{-} \mathrm{K}_{a}\right)=4.949 \mathrm{~mm}^{-1}, T=173 \mathrm{~K}$. Total 
67142 reflections, 12533 unique, $R_{\text {int }}=0.1018$. Refinement of 11198 reflections $(782$ parameters) with $I>2 \sigma(I)$ converged at final $R 1=0.0491(R 1$ all data $=0.0537)$, $w R 2=0.1379(w R 2$ all data $=0.1417)$, gof $=1.182$.

\subsection{Compound 2(3). $\mathrm{CHCl}_{3}$}

$\mathrm{C}_{121} \mathrm{H}_{89} \mathrm{Au}_{4} \mathrm{Cl}_{3} \mathrm{~N}_{12} \mathrm{P}_{4}, M=2729.16$, colourless needle, monoclinic, space group $P c, a$

$=10.389(2), \quad b=17.482(4), c=15.652(3) \AA, \beta=98.53(3)^{\circ}, U=2811.2(10) \AA^{3}, Z=$

$1, D_{c}=1.612 \mathrm{Mg} \mathrm{m}^{-3}, \mu\left(\mathrm{Mo}_{-} \mathrm{K}_{a}\right)=5.384 \mathrm{~mm}^{-1}, T=173 \mathrm{~K}$. Total 49946 reflections, 10592 unique, $R_{\text {int }}=0.1933$. Refinement of 9643 reflections (669 parameters) with $I$ $>2 \sigma(I)$ converged at final $R 1=0.0625(R 1$ all data $=0.0704), w R 2=0.1525(w R 2$ all data $=0.1591)$, gof $=1.075$.

\section{$3 \quad$ Results and discussion}

\subsection{Synthesis and characterization of compounds 1 and 2}

We have previously shown that coupling of 4,4'-diethynyl-2,2'-bipyridine and $\mathrm{R}_{3} \mathrm{PAuCl}$ in the presence of diisopropylamine and $\mathrm{CuI}$ yields gold(I) phosphanederivatized bpy ligands [20]. When this methodology was extended to the synthesis of gold(I) phosphane derivatives of 4'-ethynyl-2,2':6',2"-terpyridine, we found that it was more convenient to replace the organic base by NaOAc. Treatment of 4'-ethynyl$2,2^{\prime}: 6^{\prime}, 2^{\prime \prime}$-terpyridine with $\mathrm{R}_{3} \mathrm{PAuCl}(\mathrm{R}=\mathrm{Ph}$ or 2-tolyl $)$ in a mixture of $\mathrm{MeOH}$ and $\mathrm{CH}_{2} \mathrm{Cl}_{2}$ in the presence of $\mathrm{CuI}$ and an excess of $\mathrm{NaOAc}$ resulted in the formation, after workup, of white solids $\mathbf{1}$ and 2. In the ESI mass spectrum of $\mathbf{1}$, peaks at $\mathrm{m} / \mathrm{z}$ 1174.4 and 716.3 were assigned to $\left[\mathrm{M}+\mathrm{AuPPh}_{3}\right]^{+}$and $[\mathrm{M}+\mathrm{H}]^{+}$. For 2, the mass spectrum exhibited peaks at $m / z 1258.5,805.2$ and 758.4 , consistent with the ions [M 
$\left.+\mathrm{AuP}(\text { tolyl })_{3}\right]^{+},\left[\mathrm{Au}\left\{\mathrm{P}(\text { tolyl })_{3}\right\}_{2}\right]^{+}$and $[\mathrm{M}+\mathrm{H}]^{+}$, respectively. All isotope patterns were in accord with those simulated.

For each of compounds $\mathbf{1}$ and $\mathbf{2}$, the ${ }^{31} \mathrm{P}$ NMR spectrum showed one singlet ( $\delta 42.4$ and $24.3 \mathrm{ppm}$, respectively, in $\mathrm{CDCl}_{3}$ ) shifted to higher frequency with respect to the corresponding $\mathrm{R}_{3} \mathrm{PAuCl}$ ( $\delta 30.2$ and 5.2, respectively, in $\mathrm{CDCl}_{3}$ ). The signals in the solution ${ }^{1} \mathrm{H}$ and ${ }^{13} \mathrm{C}$ NMR spectra of $\mathbf{1}$ and $\mathbf{2}$ were assigned using COSY, DEPT, HMQC and HMBC techniques, and were consistent with the presence of a single tpy environment in each compound. In the ${ }^{13} \mathrm{C}$ NMR spectrum of 2 , a doublet at $\delta 102.4 \mathrm{ppm}\left(J_{\mathrm{PC}}=26.6 \mathrm{~Hz}\right)[33]$ was assigned to $C \equiv \mathrm{CAu}$, and this was confirmed by the observation of a cross-peak between this resonance and that of proton $\mathrm{H}^{\mathrm{B} 3}$ (see Scheme 2 for labelling). For 1, the HMBC spectrum exhibited a cross-peak between the signal for $\mathrm{H}^{\mathrm{B} 3}$ and a poorly resolved signal at $\delta 102.3 \mathrm{ppm}$, and the latter was assigned to alkyne carbon $C \equiv \mathrm{CAu}$. The resonance for the second alkyne ${ }^{13} \mathrm{C}$ nucleus was not observed in either $\mathbf{1}$ or $\mathbf{2}$, a feature that we have also reported for gold(I) phosphane 4,4'-diethynyl-2,2'-bipyridine derivatives [20].

The structures of $\mathbf{1}$ and $\mathbf{2}$ were confirmed by single crystal X-ray diffraction. Suitable crystals were grown by slow diffusion of $\mathrm{Et}_{2} \mathrm{O}$ into $\mathrm{CH}_{2} \mathrm{Cl}_{2} /$ toluene solutions of the compounds. Compound 1 (Fig. 1) crystallizes in the $P 2_{1} / c$ space group, while 2 (Fig. 2) crystallizes in space group $P-1$ with two independent molecules in the asymmetric unit. The structural features of $\mathbf{1}$ and $\mathbf{2}$ are similar. The tpy unit adopts the anticipated trans,trans-configuration and is essentially planar. The angles between the least squares planes of the pyridine rings containing $\mathrm{N} 1 / \mathrm{N} 2$ and $\mathrm{N} 2 / \mathrm{N} 3$ are $12.5(2)$ and $3.4(2)^{\circ}$ in $\mathbf{1}$, 2.6(3) and $15.5(3)^{\circ}$ in molecule A of $\mathbf{2}$, and 7.8(3) and 3.9(3) $)^{\circ}$ in molecule B of $\mathbf{2}$. The 
C8-C16-C17-Au1-P1 linkage is close to linear in each compound (see captions to Figs. 1

and 2).

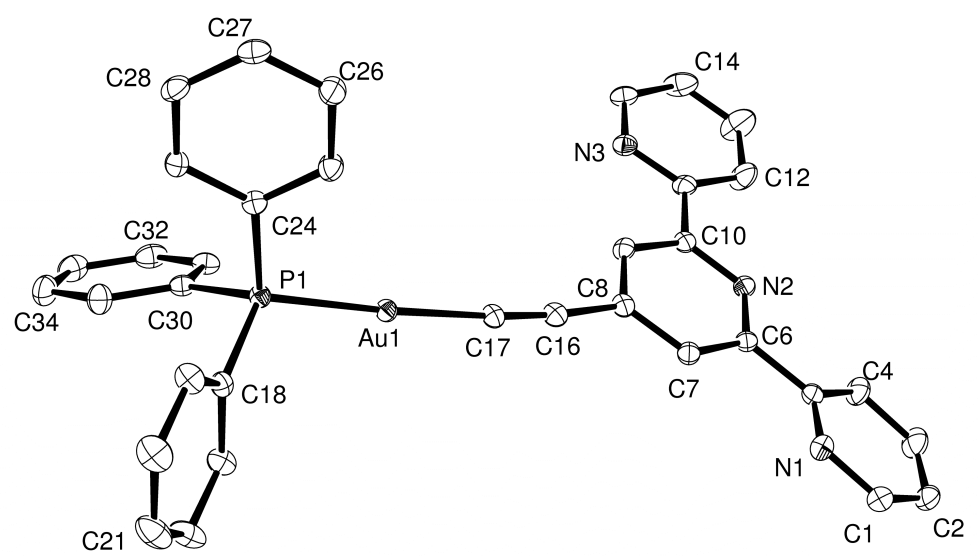

Fig. 1. Structure of compound 1 (ellipsoids plotted at 30\% probability level; $\mathrm{H}$ atoms omitted). Selected bond parameters: Au1-C17= 2.003(4), Au1-P1 = 2.2742(10), P1-C24 = 1.816(4), P1-C30 = 1.807(4), P1-C18 = 1.815(4), C16-C17 = 1.195(6) Å; C17-Au1-P1 = 176.93(11), $\mathrm{C} 16-\mathrm{C} 17-\mathrm{Au} 1=176.1(4), \mathrm{C} 17-\mathrm{C} 16-\mathrm{C} 8=172.8(4)^{\circ}$.

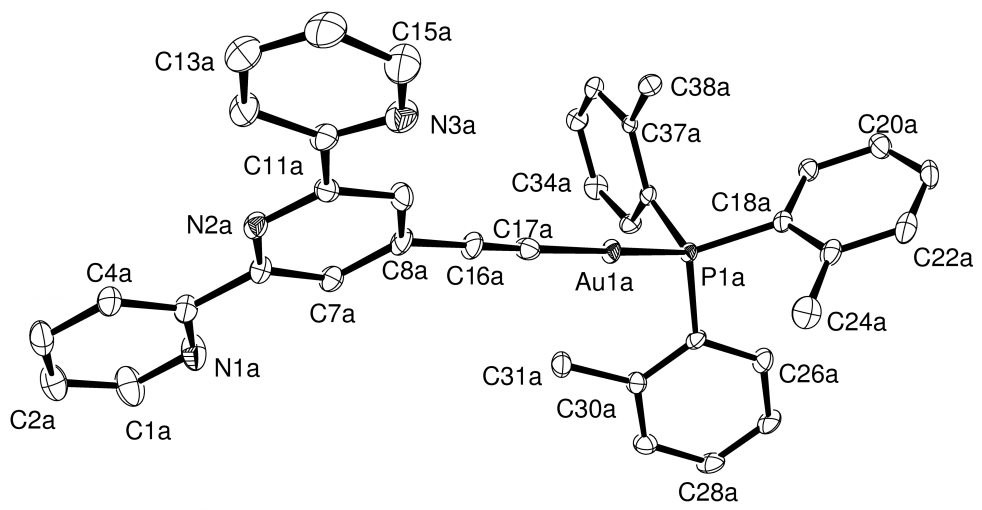

Fig. 2. One of the two independent molecules (molecule A) of $\mathbf{2}$ (ellipsoids plotted at $40 \%$ probability level; $\mathrm{H}$ atoms omitted). Selected bond parameters: Au1a-C17a = 1.996(6), Au1a-P1a = 2.2859(14), P1a-C18a = 1.815(5) P1a-C25a $=1.825(5), P 1 \mathrm{a}-\mathrm{C} 32 \mathrm{a}=$ 1.830(6), C16a-C17a = 1.187(8) Å; C17a-Au1a-P1a = 172.31(19), C16a-C17a-Au1a = 175.7(6), C17a-C16a-C8a = 178.8(8) ${ }^{\circ}$ Bond parameters for the second independent molecule (molecule B) are similar.

Figure 3 illustrates the packing of molecules of 1 in the crystal lattice. The molecules are organized to give sheets of either tpy or $\mathrm{Ph}_{3} \mathrm{PAu}$ domains. Alkyne atom $\mathrm{C} 17$ exhibits short contacts to two $\mathrm{CH}_{\text {phenyl }}$ units, one in each of two adjacent molecules $\left(\mathrm{C} 17 \ldots \mathrm{H} 27 \mathrm{a}^{\mathrm{i}} \mathrm{C} 27^{\mathrm{i}}=2.67 \AA, \mathrm{C} 17 \ldots \mathrm{H} 32 \mathrm{a}^{\mathrm{ii}} \mathrm{C} 32^{\mathrm{ii}}=2.90 \AA\right.$, symmetry codes $\mathrm{i}=-x,{ }^{1} / 2+y$, 
$1 / 2-z ; \mathrm{ii}=x, 1+y, z)$. There are no face-to-face $\pi$-interactions between adjacent tpy

units. In contrast, the tpy units in neighbouring molecules of 2 are $\pi$-stacked (Fig. 4); tpy rings containing atoms $\mathrm{N} 1 \mathrm{a}$ and $\mathrm{N} 2 \mathrm{a}$ lie over those with $\mathrm{N} 1 \mathrm{a}^{\mathrm{i}}$ and $\mathrm{N} 2 \mathrm{a}^{\mathrm{i}}$ (symmetry code $\mathrm{i}$ $=3-x, 2-y, 2-z$ ) with an optimal slipped arrangement and a separation of $3.4 \AA$.

Similarly, the rings containing $\mathrm{N} 1 \mathrm{~b}$ and $\mathrm{N} 2 \mathrm{~b}$ are stacked over those containing $\mathrm{N} 1 \mathrm{~b}^{\mathrm{ii}}$ and $\mathrm{N} 2 \mathrm{~b}^{\mathrm{ii}}$ (symmetry code $\mathrm{ii}=1-x, 2-y, 1-z$ ) at a separation of $3.5 \AA$. The tpy domains extend into layers which lie in the $a c$ plane, and consecutive tpy-sheets are separated by sheets of interlocked $\mathrm{P}\left(2\right.$-tolyl) ${ }_{3}$ units (Fig. 4).

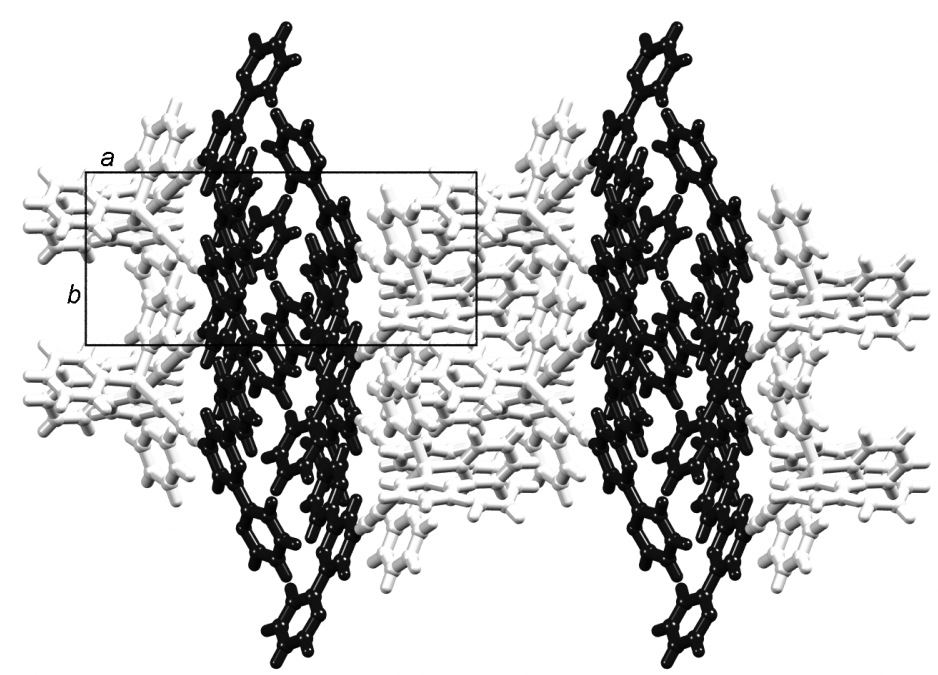

Fig. 3. View down the crystallographic $c$ axis showing the packing of molecules of $\mathbf{1}$ into domains of tpy units (two domains shown) and $\mathrm{Ph}_{3} \mathrm{PAu}$ units (three domains shown).

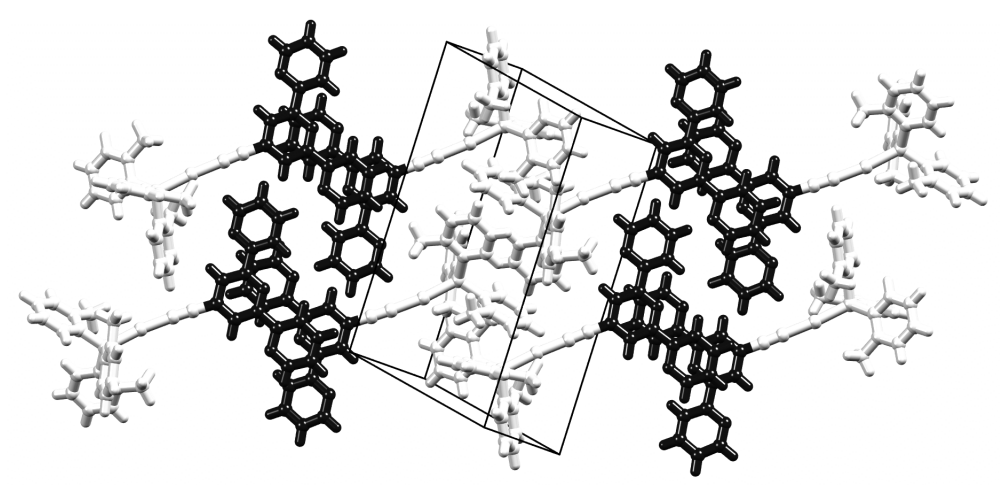

Fig. 4. Packing of molecules of $\mathbf{2}$ involves $\pi$-stacked domains of tpy units (two domains shown) separated by domains of (2tolyl) ${ }_{3} \mathrm{PAu}$ units (three domains shown). 


\subsection{Synthesis and characterization of $\mathbf{3}$}

During attempts to prepare compound $\mathbf{3}$ in a similar manner to $\mathbf{1}$ and $\mathbf{2}$, we encountered difficulties with the purification of the product, and therefore turned to the use of $\left\{\mathrm{Au}\left(4^{\prime}-\mathrm{C} \equiv \mathrm{Ctpy}\right)\right\}_{n}$ as a precursor, following the strategy adopted by Ferrer et al. for the preparation of rod-like isonitrile derivatives from treatment of $\mathrm{CNC}_{6} \mathrm{H}_{4} \mathrm{O}(\mathrm{O}) \mathrm{CC}_{6} \mathrm{H}_{4} \mathrm{OC}_{10} \mathrm{H}_{21}-p$ with $\{\mathrm{Au}(4-\mathrm{C} \equiv \mathrm{Cpy})\}_{n}$ [17]. The polymer $\left\{\mathrm{Au}\left(4{ }^{\prime}-\right.\right.$ $\mathrm{C} \equiv \mathrm{Ctpy})\}_{n}$ was prepared by reaction of $4^{\prime}$-ethynyl-2,2':6',2"-terpyridine with [(tht) $\mathrm{AuCl}]$ in the presence of $\mathrm{NaOAc}$, and the yellow solid obtained was used without purification. Treatment of $\left\{\mathrm{Au}\left(4^{\prime}-\mathrm{C} \equiv \mathrm{Ctpy}\right)\right\}_{n}$ with dppe in $\mathrm{CH}_{2} \mathrm{Cl}_{2}$ resulted, after work up, in the isolation of $\mathbf{3}$ in moderate yield. In the ESI mass spectrum, the highest mass peak envelope at $m / z 1305.8$ was assigned to $[\mathrm{M}+\mathrm{H}]^{+}$. Additional peaks were observed at $m / z 1048.6$ and 993.7 arising from the ions [Au(dppe)AuCCtpy] ${ }^{+}$ and $\left[(\mathrm{dppe}){ }_{2} \mathrm{Au}\right]^{+}$. The solution ${ }^{31} \mathrm{P}$ NMR spectrum exhibited one singlet at $\delta 40.6$ ppm, consistent with a symmetrical environment for the dppe ligand. This was supported by the observation of one signal for the methylene groups in each of the ${ }^{1} \mathrm{H}$ and ${ }^{13} \mathrm{C}$ NMR spectra, and the spectra were also consistent with the presence of one tpy environment; the resonances were assigned using COSY, DEPT, HMQC and HMBC methods. As for $\mathbf{1}$ and $\mathbf{2}$, the signal for $\mathrm{C} \equiv C A \mathrm{Au}$ was not observed, while the second alkyne carbon gave rise to a poorly resolved signal at $\delta 102.0 \mathrm{ppm}$. This assignment was confirmed by a cross-peak in the HMBC spectrum to the resonance for proton $\mathrm{H}^{\mathrm{B} 3}$.

Single crystals of $2(3) \cdot \mathrm{CHCl}_{3}$ were grown by slow diffusion of $\mathrm{Et}_{2} \mathrm{O}$ into a $\mathrm{CH}_{2} \mathrm{Cl}_{2} / \mathrm{CHCl}_{3} /$ toluene solution of $\mathbf{3}$, and $\mathrm{X}$-ray diffraction structure determination 
confirmed the molecular structure shown in Fig. 5. The two gold(I) centres are in close contact with a separation of $2.9470(8) \AA$, consistent with an aurophilic interaction [34]. In theory, the folded conformation of $\mathbf{3}$ could have resulted in face-to-face $\pi$-interactions between the two tpy units, but as Fig. 6 illustrates, this is prevented by the guest chloroform molecule. Closest contacts are C32H32a....Cl2 = 3.27 $\AA$ and C60H60a....Cl3 $=3.61 \AA$.

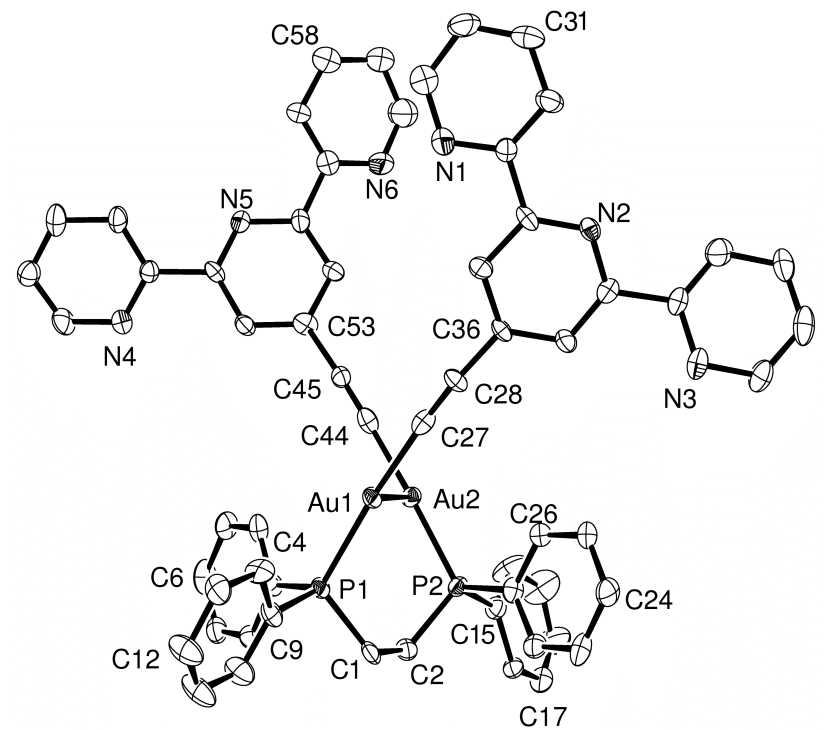

Fig. 5. Molecule of 3 in $2(3) \cdot \mathrm{CHCl}_{3}$ (ellipsoids plotted at $30 \%$ probability level; $\mathrm{H}$ atoms omitted). Selected bond parameters: Au1$\mathrm{Au} 2=2.9470(8), \mathrm{Au} 1-\mathrm{C} 27=2.015(16), \mathrm{Au} 1-\mathrm{P} 1=2.287(3), \mathrm{Au} 2-\mathrm{C} 44=2.019(19), \mathrm{Au} 2-\mathrm{P} 2=2.272(4), \mathrm{P} 1-\mathrm{C} 1=1.806(17), \mathrm{P} 1-\mathrm{C} 3=$ $1.815(14), \mathrm{P} 1-\mathrm{C} 9=1.827(17), \mathrm{P} 2-\mathrm{C} 21=1.797(14), \mathrm{P} 2-\mathrm{C} 15=1.811(16), \mathrm{P} 2-\mathrm{C} 2=1.830(16), \mathrm{C} 27-\mathrm{C} 28=1.18(2), \mathrm{C} 44-\mathrm{C} 45=1.18(2)$, $\mathrm{C} 28-\mathrm{C} 36=1.453(17), \mathrm{C} 45-\mathrm{C} 53=1.46(2) \AA \AA$; C27-Au1-P1 = 173.8(4), C27-Au1-Au2 = 96.0(4), P1-Au1-Au2 = 87.54(9), C44-Au2-P2 $=176.8(4), \mathrm{C} 44-\mathrm{Au} 2-\mathrm{Au} 1=93.5(5), \mathrm{P} 2-\mathrm{Au} 2-\mathrm{Au} 1=88.37(10), \mathrm{C} 28-\mathrm{C} 27-\mathrm{Au} 1=174.2(13), \mathrm{C} 27-\mathrm{C} 28-\mathrm{C} 36=171.0(17), \mathrm{C} 45 \mathrm{C} 44 \mathrm{Au} 2$ $=176.4(15), \mathrm{C} 44-\mathrm{C} 45-\mathrm{C} 53=175.9(17)^{\circ}$.

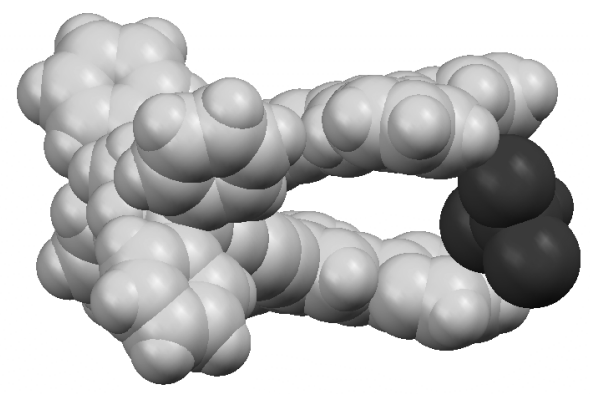

Fig. 6. Space-filling diagram to show the sandwich effect of the two tpy domains around the $\mathrm{CHCl}_{3}$ solvent molecule. 
The packing of molecules of 3 in $2(3)^{\circ} \mathrm{CHCl}_{3}$ comprises two assembly motifs. The first consists of ribbons which run parallel to the $a$-axis and are generated by face-to-face $\pi$ interactions; two out of three pyridine rings are involved (separation of rings containing $\mathrm{N} 4$ and $\mathrm{N} 2{ }^{\mathrm{i}}=3.3 \AA$, and of rings with $\mathrm{N} 5$ and $\mathrm{N} 3{ }^{\mathrm{i}}=3.5 \AA$, symmetry code $\mathrm{i}=1+x, y, z$ ), leaving the third pyridine ring protruding from one side of the ribbon (Fig. 7a). The ribbons are arranged in a herringbone fashion (Fig. 7b), the assembly being supported by $\mathrm{CH} . . \mathrm{C}_{\text {alkyne }}$ and $\mathrm{CH} \ldots \mathrm{N}^{\mathrm{i}}$ contacts, the latter involving the non- $\pi$-stacked pyridine ring: $\mathrm{C} 58 \mathrm{H} 58 \mathrm{a} \ldots \mathrm{C} 45^{\mathrm{i}}=2.86 \AA, \mathrm{C} 31 \mathrm{H} 31 \mathrm{a} \ldots \mathrm{N} 5^{\mathrm{ii}}=2.74 \AA$, symmetry codes $\mathrm{i}=x, 2-y, 1 / 2+z$, $\mathrm{ii}=-1+x, 2-y,-1 / 2+z$. This leads to short, repulsive H...H contacts $\left(\mathrm{C} 59 \mathrm{H} 59 \mathrm{a} . . \mathrm{H} 20 \mathrm{a}^{\mathrm{i}} \mathrm{C} 20^{\mathrm{i}}=2.32 \AA\right)$.

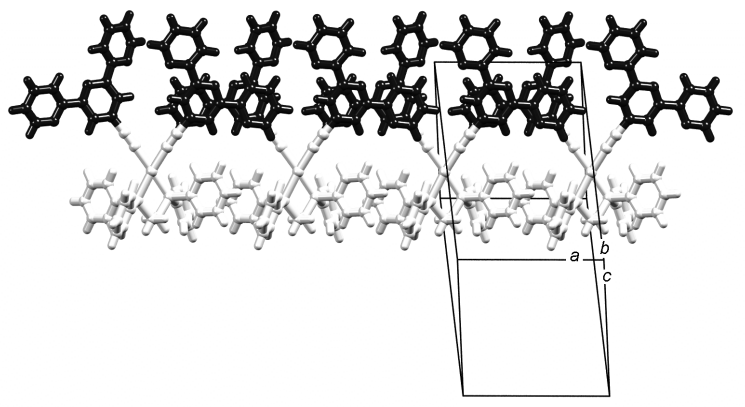

(a)

Fig. 7. (a) Assembly of a ribbon along the crystallographic $a$ axis through $\pi$-stacking of tpy domains. (b) View down the $a$ axis showing the herringbone arrangement of the ribbons.

\subsection{Photophysical properties}

The electronic absorption spectrum of a $\mathrm{CH}_{2} \mathrm{Cl}_{2}$ solution of 4'-ethynyl-2,2':6',2"terpyridine exhibits bands at 241 and $280 \mathrm{~nm}$ and a low energy tail with broad, low intensity maxima at 317 and $329 \mathrm{~nm}$ (Fig. 8). The absorptions arise from alkyne and tpy $\pi^{*} \leftarrow \pi$ and $\pi^{*} \leftarrow \mathrm{n}$ transitions. An increase in $\varepsilon_{\max }$ is observed on going from 4'- 
ethynyl-2,2':6',2"-terpyridine to each of compounds $\mathbf{1}, \mathbf{2}$ and $\mathbf{3}$, and the approximate doubling in the values of $\varepsilon_{\max }$ on going from $\mathbf{1}$ or $\mathbf{2}$ to compound $\mathbf{3}$ is consistent with the doubling of the number of tpy and alkyne units per molecule. The pattern of absorptions in the region between 260 and $310 \mathrm{~nm}$ is similar for each of compounds 1 to 3, with two maxmima at ca. 276 and $289 \mathrm{~nm}$. Based on studies of related species [21,35-38] the transitions that give rise to the observed absorption spectra are most likely to be tpy/alkyne $\pi^{*} \leftarrow \pi$ with Au orbital participation.

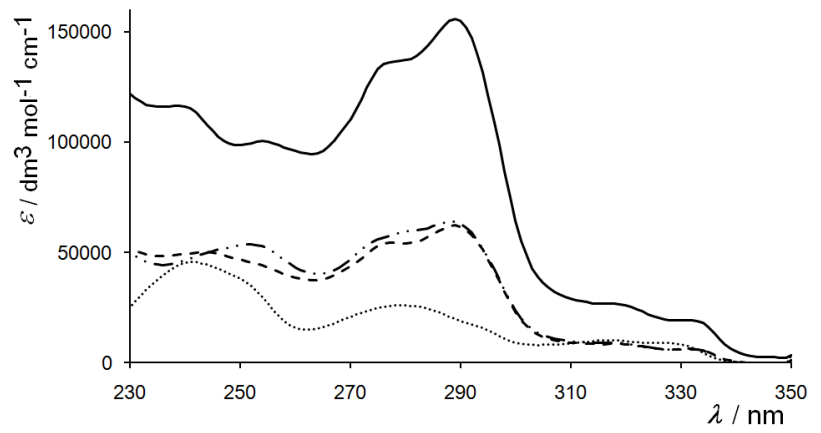

Fig. 8. Electronic absorption spectra of $\mathrm{CH}_{2} \mathrm{Cl}_{2}$ solutions of 4'-ethynyl-2,2':6',2"-terpyridine (…), 1 (---), $2(-\cdot--)$ and $3(-)$

When irradiated at $289 \mathrm{~nm}, 4^{\prime}$-ethynyl-2,2':6',2"-terpyridine emits at $351 \mathrm{~nm}$ with a high energy shoulder at $342 \mathrm{~nm}$. On going to compounds 1-3 $\left(\lambda_{\mathrm{ex}}=289 \mathrm{~nm}\right)$, the emission is resolved into two clearly defined bands at 338 and $352 \mathrm{~nm}$ for $\mathbf{1}, 339$ and 353 for 2, and 342 and $352 \mathrm{~nm}$ for 3 (Fig. 9). Excitation spectra confirm that the origins of these emissions are the broad absorptions between 230 and $300 \mathrm{~nm}$ shown in Fig. 8. 


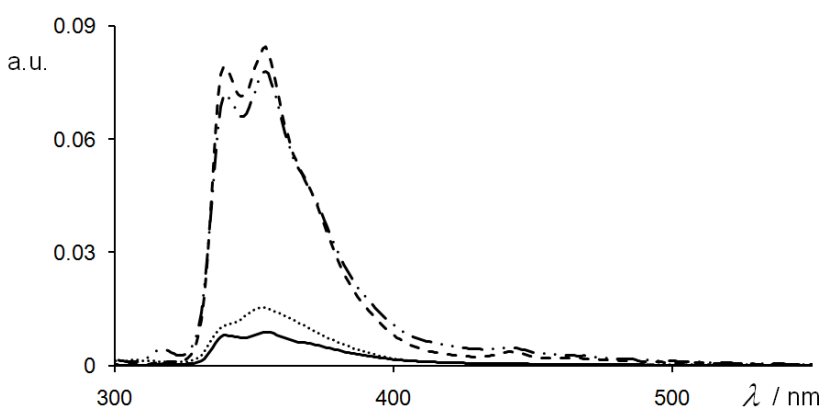

Fig. 9. Emission spectra for $\mathrm{CH}_{2} \mathrm{Cl}_{2}$ solutions of 4'-ethynyl-2,2':6',2"-terpyridine (…), $\mathbf{1}(---), \mathbf{2}(-\cdot-)$ and $\mathbf{3}(-)\left(\lambda_{\mathrm{ex}} \sim 289 \mathrm{~nm}\right)$. Concentrations: $4^{\prime}$-ethynyl-2,2':6',2"-terpyridine, $1.2 \times 10^{-5} ; \mathbf{1}, 8.4 \times 10^{-6} ; \mathbf{2}, 8.6 \times 10^{-7} ; \mathbf{3}, 4.3 \times 10^{-7} \mathrm{~mol} \mathrm{dm}^{-3}$. Slit widths: see experimental section.

Measurements of the emission spectra for compounds 1-3 were repeated approximately every minute over a period of $10-15$ minutes with $\lambda_{\mathrm{ex}}=230 \mathrm{~nm}$. The emission bands (shown for $\mathbf{1}$ in Fig. 9) decayed and new bands grew in (Fig. 10). Compared to those for $\mathbf{1}$, the new emission bands appeared at similar wavelengths for 2, suggesting that the photodegradation products were related. The changes in emission spectra of $\mathbf{3}$ as a function of time are depicted in Fig. 11. The broad band that grows in between 410 and $560 \mathrm{~nm}$ is consistent with one of the broad emissions observed upone degradation of $\mathbf{1}$ and $\mathbf{2}$, but the strong emission observed at $280 \mathrm{~nm}$ as 1 degrades (Fig. 10) is almost completely quenched in 3 (Fig. 11). When $\lambda_{\text {ex }}$ was at wavelengths higher than $230 \mathrm{~nm}$, photodecay was much slower. We have not been able to determine the identities of the photodegradation products, but note that comparable decay and growth of bands in the emission spectra of gold(I) phosphane derivatives of 4,4'-diethynyl-2,2'-bipyridine are observed over time [20]. In particular, as 1 decays, the emission centred around $570 \mathrm{~nm}$ (Fig. 10) matches that observed for the photodecay of $4,4^{\prime}-\left(\mathrm{R}_{3} \mathrm{PAuC} \equiv \mathrm{C}\right)_{2}-2,2^{\prime}$-bipyridine $(\mathrm{R}=\mathrm{Ph}$ or 4-tolyl $)$ and we suggested [20] that this arises from the formation of small gold nanoclusters [39]. 


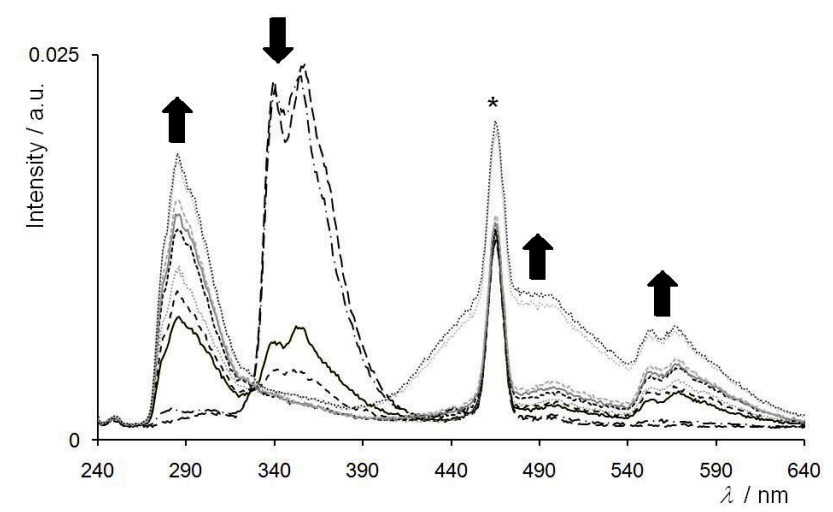

Fig. 10. Emission spectrum of 1 recorded approximately each minute over a 10 minute period $\left(\lambda_{\mathrm{ex}}=230 \mathrm{~nm}\right.$; * first harmonic).

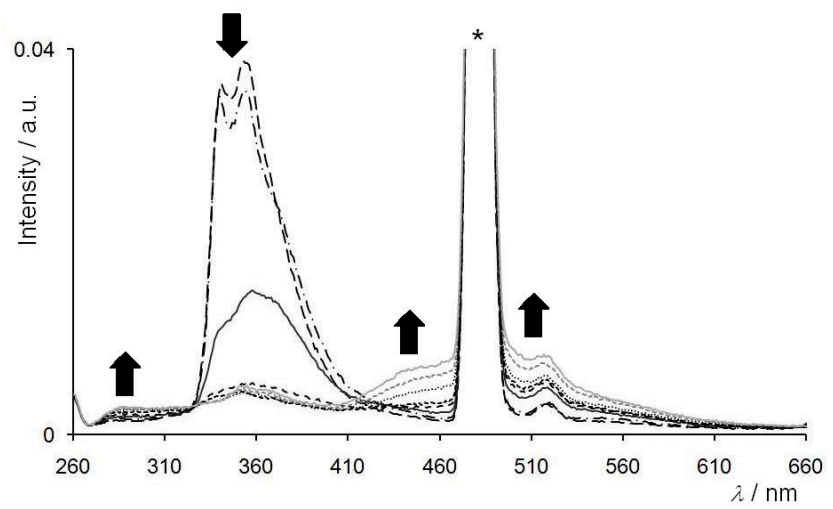

Fig. 11. Emission spectrum of 3 recorded approximately each minute over an 8 minute period $\left(\lambda_{\mathrm{ex}}=239 \mathrm{~nm} ; *\right.$ first harmonic)

\section{Conclusions}

Functionalization of 4'-ethynyl-2,2':6',2"-terpyridine with $\mathrm{Ph}_{3} \mathrm{PAu},\left(2\right.$-tolyl) ${ }_{3} \mathrm{PAu}$ or $\mathrm{Au}(\mathrm{dppe}) \mathrm{Au}$ units leads to the compounds $\mathbf{1 - 3}$ respectively which have been characterized spectroscopically in solution and by single crystal X-ray diffraction studies. In the solid state, molecules of $\mathbf{1}$ or $\mathbf{2}$ are arranged in domains of tpy or $\mathrm{R}_{3} \mathrm{PAu}$ units; in $\mathbf{2}$, the tpy units engage in face-to-face $\pi$-stacking, but analogous interactions are not observed in $\mathbf{1}$. Compound $\mathbf{3}$ crystallizes as $2(\mathbf{3}) \cdot \mathrm{CHCl}_{3}$; the dppe backbone adopts a folded conformation, bringing the two gold(I) centres within 2.9470(8) $\AA$ of one another, but $\pi$-stacking of the tpy domains is prevented by a guested $\mathrm{CHCl}_{3}$ molecule. Compounds 
1-3 are emissive in $\mathrm{CH}_{2} \mathrm{Cl}_{2}$ solution, but over a period of minutes when $\lambda_{\mathrm{ex}}=230 \mathrm{~nm}$, the emission bands decay, consistent with the photodegradation of the compounds.

\section{Appendix $1 \quad$ Supplementary data}

Crystallographic data including atomic coordinates, bond distances and angles for $\mathbf{2}$ and $\mathbf{4}$ have been deposited with the CCDC (Cambridge Crystallographic Data Centre, 12 Union

Road, Cambridge CB2 1EZ, UK; fax +44 1223336 033; e-mail: deposit@ccdc.cam.ac.uk or www: http://www.ccdc.cam.ac.uk) and may be obtained free of charge on quoting the deposition numbers CCDC 829106 - 829108.

\section{Acknowledgements}

We thank the Swiss National Science Foundation and the University of Basel for financial support.

\section{References}

[1] H. Schmidbaur, A. Schier in Comprehensive Organometallic Chemistry III, eds. R. H. Crabtree, D. M. P. Mingos, Elsevier, Oxford, 2007, vol. 2, chapter 5, p. 251.

[2] N. J. Long, C. K. Williams, Angew. Chem. Int. Ed. 42 (2003) 2586.

[3] M. J. Irwin, J. J. Vittal, R. J. Puddephatt, Organometallics 16 (1997) 3541.

[4] J. Vicente, M. T. Chicote, M. D. Abrisqueta, M. M. Alvarez-Falcón, J. Organomet. Chem. 663 (2002) 40.

[5] F. Mohr, D. J. Eisler, C. P. McArdle, K. Atieh, M. C. Jennings, R. J. Puddephatt, J. Organomet. Chem. 670 (2003) 27.

[6] G. Hogarth, M. M. Alvarez-Falcón, Inorg. Chim. Acta 358 (2005), 1386.

[7] J. Vicente, M.-T. Chicote, M. M. Alvarez-Falcón, P. G. Jones, Organometallics 24 (2005) 2764. 
[8] M.-A. MacDonald, R. J. Puddephatt, G. P. A. Yapp, Organometallics 19 (2000) 2194.

[9] W. J. Hunks, M.-A. MacDonald, M. C. Jennings, R. J. Puddephatt, Organometallics 19 (2000) 5063.

[10] F. Mohr, R. J. Puddephatt, J. Organomet. Chem. 689 (2004) 374.

[11] N. C. Habermehl, D. J. Eisler, C. W. Kirby, N. L.-S. Yue, R. J. Puddephatt, Organometallics 25 (2006) 2921.

[12] H.-S. Tang, N. Zhu, V. W.-W. Yam, Organometallics 26 (2007) 22.

[13] E. R. T. Tiekink, J.-G. Kang, Coord. Chem. Rev. 253 (2009) 1627.

[14] V. W.-W. Yam, E. C.-C. Cheng, Chem. Soc. Rev. 37 (2008) 1806.

[15] J. Vicente, M. T. Chicote, M. M. Alvarez-Falcón, Organometallics 23 (2004) 5707.

[16] R. Packheiser, A. Jakob, P. Ecorchard, B. Walfort, H. Lang, Organometallics, 27 (2008) 1214.

[17] M. Ferrer, M. Mounir, L. Rodríguez, O. Rossell, S. Coco, P. Gómez-Sal, A. Martín, J. Organomet. Chem. 690 (2005) 2200.

[18 H.-Y. Chao, W. Lu, M. C. W. Chan, C.-M. Che, K.-K. Cheung, N. Zhu, J. Am. Chem. Soc. 124 (2002) 14696.

[19] M. Ferrer, L. Rodríguez, O. Rossell, F. Pina, J. C. Lima, M. F. Bardia, X. Solans, J. Organomet. Chem. 678 (2003), 82.

[20] E. C. Constable, C. E. Housecroft, M. K. Kocik, M. Neuburger, S. Schaffner, J. A. Zampese, Eur. J. Inorg. Chem. (2009) 4710.

[21] J. Vicente, J. Gil-Rubio, N. Barquero, P. G. Jones, D. Bautista, Organometallics 27 (2008) 646.

[22] X.-L- Li, K.-J. Zhang, J.-J. Li, X.-X. Cheng, Z.-N. Chen, Eur. J. Inorg. Chem. (2010) 3449.

[23] H. Schmidbaur, Chem. Soc. Rev. 24 (1995) 391.

[24] C.-M. Che, S.-W. Lai in Gold Chemistry, ed. F. Mohr, Wiley-VCH, 2009, p. 249.

[25] See for example: P. Li, B. Ahrens, K.-H. Choi, M. S. Khan, P. R. Raithby, P. J. Wilson, W.-Y. Wong, CrystEngComm 4 (2002) 405; C. King, J.-C. Wang, Md. N. 
I. Khan, J. P. Fackler, Jr., Inorg. Chem. 28 (1989) 2145; C.-M. Che, H.-L. Kwong, V. W.-W. Yam, K.-C. Cho, Chem. Commun. (1989) 885.

[26] V. Grosshenny, F. M. Romero, R. Ziessel, J. Org. Chem. 62 (1997) 1491.

[27] M. I. Bruce, E. Horn, J. G. Matisons, M. R. Snow, Aust. J. Chem. 37 (1984) 1163.

[28] Stoe \& Cie, IPDS software v 1.26, Stoe \& Cie, Darmstadt, Germany, 1996.

[29] G. M. Sheldrick, Acta Crystallogr., Sect. A 64 (2008) 112.

[30] L. J. Farrugia, J. Appl. Cryst. 30 (1997) 565.

[31] I. J. Bruno, J. C. Cole, P. R. Edgington, M. K. Kessler, C. F. Macrae, P. McCabe, J. Pearson, R. Taylor, Acta Crystallogr., Sect. B 58 (2002) 389.

[32] C. F. Macrae, I. J. Bruno, J. A. Chisholm, P. R. Edgington, P. McCabe, E. Pidcock, L. Rodriguez-Monge, R. Taylor, J. van de Streek and P. A. Wood, J. Appl. Cryst., 2008, 41, 466.

[33] E.C. Constable, C.E. Housecroft, M. Neuburger, S. Schaffner and E.J. Shardlow, Polyhedron, 2008, 27, 65.

[34] F. Mendizabal , P. Pyykkö and N. Runeberg, Chem. Phys. Lett., 2003, 370, 733; P. Pyykkö, Angew. Chem. Int. Ed., 2002, 41, 3573.

[35] D. Li, X. Hong, C. M. Che, W. C. Lo and S. M. Peng, J. Chem. Soc., Dalton Trans., 1993, 2929.

[36] M. Ferrer, A. Gutierrez, L. Rodriguez, O. Rossell, J. C. Lima, M. Font-Bardia and X. Solans, Eur. J. Inorg. Chem., 2008, 2899.

[37] V. W.-W. Yam, S. W.-K. Choi and K.-K. Cheung, Organometallics, 1996, 15, 1734.

[38] V. W.-W. Yam and S. W.-K. Choi, J. Chem. Soc., Dalton Trans., 1996, 4227.

[39] Y. Bao, C. Zhong, D. M. Vu, J. P. Temirov, R. B. Dyer and J. S. Martinez, J. Phys. Chem. C, 2007, 111, 12194. 